\title{
DOMESTIC TOURIST SATISFACTION IN A COLONIAL HOTEL AND ITS IMPLICATIONS FOR MANAGEMENT: THE CASE OF BANDARAWELA HOTEL
}

\author{
Hanshika Madushani Herath ${ }^{1}$ and Sarath Munasinghe ${ }^{2}$ \\ ${ }^{1}$ University College of Rathmalana, University of Vocational Technology, Sri Lanka \\ ${ }^{2}$ Faculty of Management Studies, Sabaragamuwa University of Sri Lanka
}

\begin{abstract}
The most important job and the biggest challenge in contemporary management in service industries, is making the customers satisfied. It can be argued that the difficulty faced by managers committed to customer satisfaction, is designing specific customer satisfaction strategies. This task becomes a challenge due to the lack of studies done to measure customer satisfaction in hospitality industry, which result in the lack of understanding of the governing factors and the level of customer satisfaction. In Bandarawela Hotel the significant differences between the satisfaction of domestic and foreign tourists and the dominant dissatisfaction of domestic tourists have been recognized. The reasons for dissatisfaction were studied using the mixed methodology of the research. The factors affecting their satisfaction were recognized to be in two categories; tangible and intangible. As the significant findings, some features of the hotel that exists due to the Colonial concept were recognized as the main factors that contribute to the domestic tourists' dissatisfaction.
\end{abstract}

Keywords: Bandarawela Hotel, Guest Satisfaction, Domestic Tourist

\section{INTRODUCTION}

The contribution of the tourism industry to the country's economic growth is undeniably significant although the industry is a late entrant to the mainstream of the Sri Lankan economy. This industry is being increasingly recognized as an important player in the economic growth. This is evident in the strategic plan for tourism in Sri Lanka where it is expected to draw 2.5 million tourists by 2016 (Tourism Development Strategy 2011-2016). A special feature that is relevant to this study in this development strategy is that the government's special attention paid to improve domestic tourism.

The problem under investigation was revealed in a preliminary study of reviewing guest comment sheets on the hotel experience of Bandarawela Hotel, Sri Lanka. The review disclosed an unusual nature of the guest satisfaction. That is, the guest satisfaction for the same product was on two different directions; a significant amount of foreign guests were satisfied in their overall evaluation of the hotel experience, while another significant amount of domestic visitors were complaining over the quality of accommodation and other amenities in the hotel. Accordingly, the objectives of this research were to investigate into this difference of satisfaction levels and to recognize the factors leading to domestic guests' dissatisfaction.

Being a reputed hotel in Bandarawela area that receives a significant amount of domestic tourists as customers, investigating this unusual behavior of the guest satisfaction will be crucial for making satisfied customers.

Bandarawela Hotel is a colonial heritage in the Uva province of Sri Lanka; is the first hotel in the hill country and the history of which goes back to the year 1893. Its antecedents are read from the end of 19 th century when it first ran as a guest house. From the beginning, Bandarawela Hotel was conceived as an exclusive club and guest house for Europeans only. Its opening in 1894 coincided with the extension of the rail link from Nanu Oya to Bandarawela. Train travelers needed a place to stay overnight and the Hotel provided an ideal facility for them. With time it became an exclusive recluse for 
the Europeans who were resident in Sri Lanka and was nurtured to be so until the 1950 's. It even served as a convalescent home for recuperating British soldiers during World War II. Year 1924-1926 Miller \& Co purchases The Bandarawela Hotel from the government of Ceylon with the sanction of the Secretary of State for the colonies. Year 1983 Management of Bandarawela Hotel is handed over to Aitken Spence Hotel Managements (pvt) limited.

\section{LITERATURE REVIEW}

Customer satisfaction is basically post consumption evaluation concerning a specific product or service. Satisfaction level is a result of the difference between expected and perceived performance of a product or a service. It occurs when product or service is better than what is expected. Given the vital role of customer satisfaction, it is not surprise that a variety of research have been devoted to investigate the determinants of satisfaction. Basically, satisfaction can be determined by subjective (e. g. customer needs, emotions) and objective factors (e. g. product and service features).

It is necessary to obtain high levels of customer satisfaction for the service supplied in the hospitality industry. Prior understanding of guest perception regarding the hotel attributes is significant. According to the Kone 2006, the miracle of success in hotel development occurs when the business can provide not only the target needs of the guest but exceeds their expectations. A research done by Scott (2008) defined guest perception of hotel attributes can be recognized as the degree to which guests may find various services and number of different services within the same or different buildings which are often available for the use of both residents of the hotel and non-residents. According to Scott, hotel's attributes such as cleanliness, price, location, and security, personal service, physical attractiveness, opportunities for relaxation, standard of services, appealing image, and reputation can be accepted as prominent by travelers to review the quality of the hotel.

The major types of services provided in the hospitality industry can be classified into three main types: accommodation, food and drink apart from miscellaneous services and entertainment. It is important to note that the extent of these services being made available to customers tends to vary with the size of the establishments and types of organization. The industry provides a range of accommodation services. According to the Cooper, Fletcher, Gilbert and Wan hill (1996), they suggested that accommodation provides an essential support service to satisfy the wider motivation that brought the visitor to the destination.

Hotels must therefore ensure that they provide the kind of services that will satisfy current customers and motivate new ones. The most recurring satisfaction attributes were room related aspects such as cleanliness of rooms and excellent performance by housekeeping department (Prayukvong, Sophon, Hongpukdee, \& Charapas, 2007). The previous researchers have recognized the following factors as the components of customer satisfaction in hotels.

As same as the accommodation, selling of food and drink is very important aspect of hospitality service, however the provision of such service requires more personnel compared to provision of accommodation. Hence, these aspects can be classified as core offerings of hospitality industry. According to the Oliver's expectancy disconfirmation theory (Oliver 1997), when providing core products to the customers, realization of guests' expectation is vital factor for their satisfaction.

In addition, Barsky and Lebagh (1992) stated that employee attitude, location and rooms are likely to influence travelers' satisfaction. According to Kuo (2007), due to the close interaction between hotel employees and customers, service attitude of the employees plays a critical role in maximizing customer satisfaction.

Customer service and hospitable behavior is a system of activities that comprises customer support systems, complaint processing, and friendliness and speed of service delivery. The key to achieve competitive advantage lies in delivering high quality service that results in satisfied customers (Shemwell et al, 1998). Service quality and customer satisfaction are key factors in the battle to obtain competitive advantage and customer retention. 
Although many studies have been conducted on customer satisfaction, most of them were focused on antecedent and consequences of guest satisfaction. However, less work has been done on hotel concept related factors and guest satisfaction. Hence, it is important to conduct a study that uncovers areas of customer satisfaction which is useful for management who are committed to customer satisfaction to make improvement.

\section{Colonial concept and its legal restrictions for hotel operation and design}

Bandarawela Hotel has been conserved as a monument under the Antiquities (Amendment) Act, No24 of 1998. According to the Act, Minister of cultural affairs may by Order in writing' declare that any specified monument which dates or is believed to date period prior to the 1 st day of January, 1850 deemed to be an ancient monument. Accordingly, Bandarawela Hotel is declared as an Archeological conserved building and a monument upon the publication in the Gazette notification of the order No. 1586, under section 19, on 23rd of January 2009.

According to the Ordinance, any ancient monument situated on any land other than crown land is in danger of destruction or removal, or damage from neglect or injudicious treatment, and that it is in the public interest that such monument should be protected, by order published in the Gazette declare such monument to be a protected monument. In addition, the ordinance mentioned that, no person shall, except under the authority and in accordance with the conditions of a permit issued by the Archeological Commissioner, or in accordance with an agreement entered into under section 20, commence or carry out any work of restoration, repair, alteration or addition in connection with any protected monument within the hotel premises [Antiquities (Amendment) Act (1998)]. Due to those regulations, as a conserved monument, Bandarawela Hotel couldn't make any refurbishments, changes to the original structure and modifications to expand their operation.

\section{METHODOLOGY}

This study took both qualitative and quantitative methods for data collection and analysis. Both primary and secondary data were used. Secondary data were collected from the review of guest comments and primary data were collected from questionnaire survey. Both domestic guests and foreign guests were considered for the feedback review and only the domestic tourists were considered for further study by using questionnaire survey as it is the target group of the study.

The questionnaires consist of three parts. First part of the questionnaire contains questions pertaining to the profile of respondents, which is designed to gain insights related to a profile of domestic tourists. The second part contained items that explore customer satisfaction with respect to hotel services. In this part, the guests were asked to rank their satisfaction in relation to different services at one of three levels; satisfied, dissatisfied and moderately satisfied. The third part of the questionnaire measures customers' post purchase behavior by asking questions related to their intentions to return and to recommend the hotel to potential customer(s). A total of 45 questionnaires were distributed to the respondents and 35 questionnaires were completed and returned to be analyzed. Therefore, the response rate of the study is $78 \%$.

The collected data was subjected to multipleregression analysis. The reliability of the scale was assessed by subjecting the scale measuring tourists' satisfaction to a reliability test. Stepwise multiple regression analysis was employed to determine the identified factors of guests' satisfaction (independent variables) whose values are known to predict the single dependent variable, which in this case is the domestic tourists' satisfaction in Bandarawela Hotel.

\section{ANALYSIS AND FINDINGS}

\section{Profile of Respondents}

The respondents were mainly from Western Province (80\%), mostly coming from Colombo, Nugegoda and Kelaniya areas. Their ages ranges from 35 and above (77\%), representing more female participation (60\%). In addition majority of the respondents were professionals and executives $(63 \%)$ by their occupation. Most of the respondents indicated that their purpose of visit to Bandrawela Hotel was holiday and recreation (69\%), business purposes 
(20\%), and visiting friends and relatives (11\%). It should be noted that majority of respondents were unaware of the hotel concept of colonialism before their arrival $(52 \%)$ and that the hotel is colonial old charm hotel which is a monument of British period. In addition from the above respondents first time visitors to the hotel was significantly high (54\%).

\section{Factors affecting domestic tourists' satisfaction}

Factor analysis of guest satisfaction and their positive and negative relationship applied to the statistical analysis, as illustrated in table 01 to 03 .
As illustrated in the table 01 the results of the test indicated computed Cronbach's alpha values of 0.953 for customer satisfaction. According to Carmines and Zeller (1979) a Cronbach's alpha value of above 0.7 is considered to be reliable. Therefore it is comfortable to proceed to further analysis of the data.

Table 01-Reliability Statistics

\begin{tabular}{|l|l|}
\hline Cronbach's Alpha & N of Items \\
\hline .953 & 17 \\
\hline
\end{tabular}

To investigate the influence of each determinant upon domestic tourists' satisfaction, an analysis was conducted to assess the significance of the relationships between each independent variable and the dependent variable. The dependent variable is domestic tourists' satisfaction and four independent variables are price, hospitable behavior, accommodation $\&$ amenities and food $\&$ beverages.

Based on the analysis findings are illustrated in table 02 . The $\mathrm{R}$ vale of 0.825 indicates a strong correlation between the independent variables and domestic tourists' satisfaction, the coefficient of the determinant $\left(\mathrm{R}^{2}\right)$ was 0.68 which representing the proportion of variation in the domestic tourists' satisfaction that is accounted by the independent variables and the adjusted $\mathrm{R}^{2}$ was 0.637 . According to the results of stepwise multiple regression analysis, these variables, namely, price, hospitable behavior, accommodation \& amenities and food \& beverages explain almost $64 \%$ percent variation in domestic tourists' satisfaction.

Table 02- Model summary

\begin{tabular}{|l|l|l|l|l|}
\hline Model & R & R Square & Adjusted R Square & Std. Error of the Estimate \\
\hline 1 & $.825^{\mathrm{a}}$ & .680 & .637 & .45942 \\
\hline
\end{tabular}

a. Predictors: (constant), price, food and beverages, accommodation \& amenities and hospitable behavior

The SPSS output in Table 3 indicates the levels of statistical significance. In order to assess the relative importance, beta coefficients were used: the higher the beta coefficients, the more important each determinant. It is important to note that majority of factors to be statistically significant $\quad(p<.01)$ antecedents influencing domestic tourists' satisfaction in Bandarawela Hotel. The most important factor affecting domestic tourists' satisfaction was found to be "Accommodation \& amenities" with a beta value of 0.501 , followed by "Food \& Beverages" with 0.461 , "Price" with 0.197 and "Hospitable behavior" with -0.170 was found to be the least important factor affecting domestic tourists' satisfaction in Bandarawela Hotel. 
In this particular case it is apparent that significant value for food \& beverage is 0.278 , followed by hospitable behavior 0.745 and price 0.183 and accommodation \& amenities significant value is 0.047 which represents the lowest rate. This means that accommodation \& amenities directly influence over the dominant dissatisfaction of domestic tourists, because, it is a lower value than the accepted significant level of 0.05 . Accordingly, the regression analysis showed that accommodation \& amenities was significant to be identified as a good predictor of the overall domestic tourists' satisfaction (Sig. $\mathrm{T}<0.05)$ in Bandarawela Hotel.

Table 03-Coefficients

\begin{tabular}{|c|c|c|c|c|c|}
\hline \multirow{2}{*}{ Model } & \multicolumn{2}{|c|}{$\begin{array}{c}\text { Unstandardized } \\
\text { Coefficients }\end{array}$} & $\begin{array}{c}\text { Standardized } \\
\text { Coefficients }\end{array}$ & Sig. \\
\cline { 2 - 6 } & B & Std. Error & Beta & .746 & .462 \\
\hline Food \& Beverages & .435 & .394 & .461 & 1.104 & .278 \\
Accommodation & .447 & .216 & .501 & 2.073 & .047 \\
Hospitable behavior & -.166 & .507 & -.170 & -.328 & .745 \\
Price & .156 & .115 & .197 & 1.364 & .183 \\
\hline
\end{tabular}

a. Dependent variable: domestic tourist satisfaction

Findings indicated that the domestic tourists' dissatisfaction in Bandarawela hotel was directly influenced by accommodation $\&$ amenities. This fact was statistically proved by "beta" coefficient of 0.501 and a " $t$ " score of 2.073 . For reliability purposes, it is important to note that this factor received a finding of 0.796 as regards the usage of Cronbach's alpha measurement. When it comes to significance, there is a significant relationship between the two constructs (0.047). It must be noted here that the current state of accommodation $\&$ amenities is based on the colonial concept. Being a colonial hotel, the hotel is not in a position to change the quality level due to legal restrictions. Accordingly, this aspect related to the colonialism concept can be recognized as a principal factor of domestic tourists' dominant dissatisfaction in Bandarawela Hotel.

Undoubtedly, increasing guest satisfaction is important since securing customer retention would fail without making them satisfied. In order of doing this effectively, the first step is to recognize the factors that drive customer satisfaction. Next, the management should consider the relative importance of those factors for guest satisfaction. Perhaps, this is useful for hoteliers to focus their efforts on developing strategies to enhance core aspects of customer satisfaction, which contribute to improving customer retention.

In this respect, the above findings of this study draw the attention of the management to an important factor, among others. This study identified four underlying aspects of domestic tourists' satisfaction; accommodation $\&$ amenities, food $\&$ beverages, price and hospitable behavior. The analysis showed that the quality of accommodation \& amenities, that is determined by the hotel concept (in the context of this particular hotel) have significant effect on domestic tourists' satisfaction. Specifically, most of the domestic visitors have been dissatisfied about the factor while they have been satisfied with other factors.

However, it was further noted that the domestic tourists prior knowledge of this hotel been a colonial hotel was very week. In other words, most of the domestic tourists were not aware that the hotel is such a concept-based hotel and that the nature of 
accommodation \& amenities are different to that of other hotels. On the contrary, it can be assumed here that foreign tourists who come through travel agents receive this information from the travel agents and thus they are aware of this fact before they come. This prior knowledge of the nature of the product surely influences on forming the expected service quality and thus, as a result, influence upon guests' level of satisfaction. Accordingly, by looking at the domestic tourists' level of satisfaction regarding the accommodation \& amenities and their prior knowledge of the hotel concept, it can be concluded here that the colonial concept is not a good Unique Selling Proposition (USP) for the domestic tourists in the hotel.

Considering the purpose of visit, most of the respondents have visited the hotel for holiday and recreation, traveling either with their spouse or friends. It was observed in the data that, there were several factors which influence on the selection of Bandarawela Hotel. Among them, the reputation of the hotel as a member of Aitken Spence Hotel Chain, the convenience due to the close location of the hotel to Bandarawela city and Bandarawela railway station were significant.

Further, based on the data gathered, it was recognized that comparing to foreign tourists, prior knowledge of domestic tourists about the hotel concept and related facilities \& amenities was very little. It can be assumed here that this fact can lead the domestic and foreign tourists to have different levels of expectations about service quality and thereby different levels of satisfaction.

\section{CONCLUSIONS}

Based on the analysis, a few points can be concluded in this study. The first is that the majority of the domestic tourists who visit the particular hotel for holiday making and the visitors represent the Western Province of the country. Further, although they select this particular hotel, they are not that aware of the nature of the hotel and thus expect the accommodation and amenities that are offered at typical hotel. Since the hotel is not in a position to offer the luxury that other hotels can offer due to its theme, the average domestic tourist is not satisfied about the quality of accommodation and amenities. Thus, it can be concluded that the colonial concept is not a good Unique Selling Proposition for domestic tourists as far as this particular hotel is concerned.

\section{REFERENCES}

Barsky, J.D. (1992). Customer Satisfaction in the Hotel Industry: Meaning and Measurement. Hospitality Research Journal, 16(1): 51-73.

Carmines, E. G., \& Zeller, R. A. (1979). Reliability and validity assessment. Thousand Oaks, CA: Sage.

Cooper C., Fletcher J., Gilbert D. and Wanhill S. (1996). Tourism: Principles and Practice, Longman, London

Government Gazette of the Democratic Socialist Republic of Sri Lanka. Antiquities (Amendment) Act. (1998). No. 24 of 1998.

Kone D.L. (2006). Land Development 10th ed., Buildersbooks.com, Washington D.C. USA

Kuo, C. (2007). The importance of hotel employee service attitude and satisfaction of 36 international tourists. The Service Industries Journal, 27(8), 1073-1085.

Oliver, R.L. (1980). A Cognitive Model of the Antecedents and Consequences of Satisfaction Decisions. Journal of Marketing Research, 17: 460-469.

Prayukvong, W., Sophon, J., Hongpukdee, S., \& Charapas, T. (2007). Customer's satisfaction with hotel guestrooms: A case study in Ubon Rachathari province, Thailand. Asia Pacific Journal of Tourism Research, 12(2), 119-126.

Scott B. (2008). Hotels in the edited book Valuation: Principles into Practice 6th ed. Pg 463 EG books London.

Shemwell,D.J.,Yavas,U.\& Bilgin,Z.(1998). CustomerService Provider Relationships:

An Empirical Test of a Modem of Service Quality. Satisfaction and Relationship-Oriented Outcomes, 9 (2), 155-68.

Sri Lanka Tourism Development Authority. (2010). Key Statistical Indicators 2010.

Sri Lanka Tourism Development Authority. (2011). Tourism Development Strategy 2011-2016 